\title{
Mutual antagonism of estrogen receptors $\alpha$ and $\beta$ and their preferred interactions with steroid receptor coactivators in human osteoblastic cell lines
}

\author{
D G Monroe, S A Johnsen, M Subramaniam, B J Getz, S Khosla ${ }^{1}$, \\ B L Riggs ${ }^{1}$ and T C Spelsberg \\ Department of Molecular Biology and Biochemistry, Mayo Clinic and Mayo Foundation, 200 1st Avenue SW, Rochester, Minnesota 55905, USA \\ ${ }^{1}$ Endocrine Research Unit, Mayo Clinic and Mayo Foundation, Rochester, Minnesota 55905, USA \\ (Requests for offprints should be addressed to D G Monroe; Email: Monroe.David@mayo.edu)
}

\begin{abstract}
Estrogen is a major sex steroid that affects the growth, maintenance, and homeostasis of the skeleton. Two isoforms of the estrogen receptor $(\operatorname{ER} \alpha$ and $\operatorname{ER} \beta)$ mediate the transcriptional effects of estrogen. Although both isoforms of ER are present and functional in some human osteoblast $(\mathrm{OB})$ cell lines, there is minimal information on the differential regulation of transcription by ER $\alpha$ and ER $\beta$ homo- or heterodimers. This report demonstrates that $\operatorname{ER} \alpha$ and $\operatorname{ER} \beta$ coexpression decreases the transcriptional capacity (relative to each ER isoform alone) on an estrogen response element-dependent reporter gene in OBs but not in other non-osteoblastic cell lines. These data suggest that ER $\alpha$ and ER $\beta$ coexpression can differentially influence the degree of transcriptional activation in certain cell types. Interestingly, the overexpression of the
\end{abstract}

steroid hormone receptor coactivator-1 (SRC1) resulted in preferential transcriptional enhancement by $\operatorname{ER} \beta$ as well as coexpressed ER $\alpha$ and ER $\beta$, whereas SRC2 overexpression appeared to preferentially enhance ER $\alpha$ transactivation. SRC3 overexpression failed to enhance estrogen-dependent transcription of any ER combination in OBs. Similar overexpression experiments in COS7 cells exhibited preferential enhancement of $\mathrm{ER} \alpha$ function with all SRCs, including SRC3. Our data also demonstrated that SRC3 mRNA is reduced in osteoblastic cells, suggesting that SRC3 may have only a minor role in these cells. These data suggest that the transactivation capacity of various ER isoforms is both SRC species and cell type dependent.

Journal of Endocrinology (2003) 176, 349-357

\section{Introduction}

Estrogen is involved in mediating important physiological processes in numerous target tissues including breast, uterus, brain, and bone (reviewed in Rickard et al. 2000). The effects of estrogen were initially considered to be mediated by a single estrogen receptor (ER $\alpha)$ (Mangelsdorf et al. 1995); however, a second estrogen receptor $(\operatorname{ER} \beta)$ that increases the potential diversity of estrogen responses was discovered (Kuiper et al. 1996, Mosselman et al. 1996, Tremblay et al. 1997). The two ER isoforms function by binding $17 \beta$-estradiol (E2) with high affinity. The 'activated' receptor isoforms subsequently dimerize with either themselves (e.g. forming homodimers) or with the other ER isoform (e.g. forming heterodimers) (Cowley et al. 1997). The receptor recognizes specific cis-acting DNA elements (estrogen response elements or EREs) located within the regulatory regions of target genes and activates transcription through recruitment of numerous coactivators and components of the basal transcriptional machinery. ER $\alpha$ and $\operatorname{ER} \beta$ share significant homology within the DNA-binding domain and ligand-binding domains (Rickard et al. 2000), suggesting that both ER isoforms bind similar ligands and EREs (Yi et al. 2002). However, significant differences in tissue specificity and responses to certain antiestrogens (Paech et al. 1997) demonstrate that the ER isoforms are unique and may perform different functions in different cell types.

It is well accepted that estrogen plays a pivotal role in bone cell metabolism and overall skeletal homeostasis, which involves the regulatory actions of the bone-forming osteoblasts (OBs). The development of specific ER knockouts in mice has proven useful in understanding estrogen action on the skeleton. Homozygous deletion of the ER $\alpha$ gene in mice (ERKO) results in decreased longitudinal bone growth, decreased cortical bone density, as well as decreased bone formation (Korach et al. 1996, Lindberg et al. 2002), suggesting that ER $\alpha$ is of critical importance in promoting overall bone growth. In contrast, 
homozygous deletion of the ER $\beta$ gene in female mice (BERKO) results in increased longitudinal bone growth and increased bone mineral density (Windahl et al. 1999, Lindberg et al. 2002, Sims et al. 2002). Taken together, these data suggest that ER $\beta$ may exert a negative effect on ER $\alpha$-mediated bone growth in mice. Although this concept of ER $\beta$ antagonism has been suggested in other cell systems (Hall \& McDonnell 1999, Pettersson et al. 2000), the physiological consequences of ER $\beta$ coexpression with $\mathrm{ER} \alpha$ in bone cells, such as OBs, are unknown. The adoption of similar principles of ER function between the animal and human skeleton is complicated by the observation that, in contrast to current mouse models, a natural mutation of ER $\alpha$ in man, which inactivates the receptor, results in continued longitudinal bone growth (Smith et al. 1994). This suggests that estrogen has different effects on ER $\alpha$-mediated bone growth in humans and mice. Thus, the understanding of ER isoform actions and interactions in a human $\mathrm{OB}$ system is critical to developing models for estrogen action on the skeleton and developing new selective ER modulators for the clinical treatment of osteoporosis.

Nuclear hormone receptor coactivators are involved in enhancing the ligand-dependent transcriptional signal of numerous nuclear hormone receptors, including ER. The p160 family of coactivators includes steroid hormone receptor coactivator (SRC)-1 (also called p160/ ERAP160) (Onate et al. 1995), SRC2 (also called GRIP1 and TIF2) (Voegel et al. 1996), and SRC3 (also called TRAM1, ACTR, AIB1, RAC3, and p/CIP) (Li et al. 1997). Gene deletion experiments in mice demonstrate that while homozygous deletion of SRC1 results in partial hormone resistance (Xu et al. 1998, Weiss et al. 1999), the phenotype of SRC1 null mice otherwise appears largely normal. Interestingly, the SRC3 null mice demonstrate dwarfism and a more severe reproductive phenotype (Xu et al. 2000). However, the ultrastructure, densitometry, and skeletal/bone growth patterns have not been examined in any SRC knockout model, nor have the coactivation properties of the SRCs been studied in a human OB system.

This paper addresses several important and novel aspects of ER function in OBs: the interactions between and transcriptional regulation by coexpressed $\mathrm{ER} \alpha$ and $\mathrm{ER} \beta$, the effects of SRC overexpression on ER-dependent transcription, and the comparison of these effects between osteoblastic and non-osteoblastic cells. As a first step to understanding these aspects of ER function in human $\mathrm{OBs}$, it is important to first characterize these responses.

\section{Materials and Methods}

\section{$D N A$ constructs and reagents}

Full-length cDNAs for $\operatorname{ER} \alpha$ and $\operatorname{ER} \beta$ containing an $N$-terminal FLAG epitope were constructed in the
pcDNA4/TO expression vector (Invitrogen, Carlsbad, CA, USA) using PCR. Briefly, oligonucleotide primers were designed to amplify the full-length ER $\alpha$ (amino acids $1-595)$ that contained BamHI and XhoI restriction sites ( $5^{\prime}$ and $3^{\prime}$ respectively) for subcloning into pcDNA4/ TO. Full-length ER $\beta$ (amino acids 1-530) was constructed using primers containing HindIII and XbaI restrictions sites ( $5^{\prime}$ and $3^{\prime}$ respectively) and subsequent subcloning into pcDNA4/TO. A construct containing a canonical ERE upstream of luciferase (ERE-TK-LUC) was used as a reporter in transfection experiments. pRL-TK (expressing Renilla luciferase) was used as a transfection efficiency control (Promega, Madison, WI, USA). The ER antagonist ICI 182,780 was generously provided by Zeneca Pharmaceuticals (Macclesfield, Cheshire, UK) and E2 was purchased from Sigma (St Louis, MO, USA).

\section{Cell culture and transfection}

Human fetal osteoblasts (hFOB) (Harris et al. 1995) were maintained in phenol-red free Dulbecco's modified Eagles's medium (DMEM)/F12 media containing $10 \%(\mathrm{v} / \mathrm{v})$ fetal bovine serum (FBS) supplemented with $300 \mathrm{mg} / \mathrm{l} \quad \mathrm{G} 418$ and $1 \times$ antibiotic/antimycotic (Invitrogen). MG63, COS7, Hs578T, U2OS and SaOS2 cells were maintained in the same media lacking the G418 selection. All cells were transfected at a density of 50\% in six-well dishes in serum-free media with the indicated amount of ER expression plasmid, 1.0 $\mu \mathrm{g}$ ERE-TK-LUC, and $1.0 \mu \mathrm{g}$ pRL-TK using lipofectamine PLUS reagent (Invitrogen). Three hours after transfection, the hFOB cells were washed and treated with ICI 182,780 (10 nM) in DMEM/F12 media containing 10\% (v/v) charcoalstripped FBS for $24 \mathrm{~h}$ to eliminate basal estrogenindependent activation of the reporter construct. All other cell lines were maintained in similar media lacking ICI 182,780 during this period. Subsequently, the cells were treated either with ethanol vehicle or $10 \mathrm{nM}$ E2 in DMEM/F12 media containing 10\% (v/v) charcoalstripped FBS for an additional $24 \mathrm{~h}$. It is important to mention that following removal of the ICI 182,780 from the hFOB cell media, no subsequent estrogenindependent activation of the reporter construct was observed in the absence of E2 during the 24-h treatment period (data not shown). The cells were harvested and $30 \mu \mathrm{l}$ cell extract was assayed using the Dual Luciferase Reporter System (Promega) with a Turner Designs 20/20 luminometer (Sunnyvale, CA, USA). Promoter activity was quantified as a ratio of firefly luciferase to Renilla luciferase (expressed as relative light units; RLU). Experiments were repeated three times and a representative experiment is shown.

\section{Western blot analysis}

hFOB cells were transfected with $1.0 \mu \mathrm{g}$ ER $\alpha$ or ER $\beta$ expression plasmid using lipofectamine PLUS reagent. 

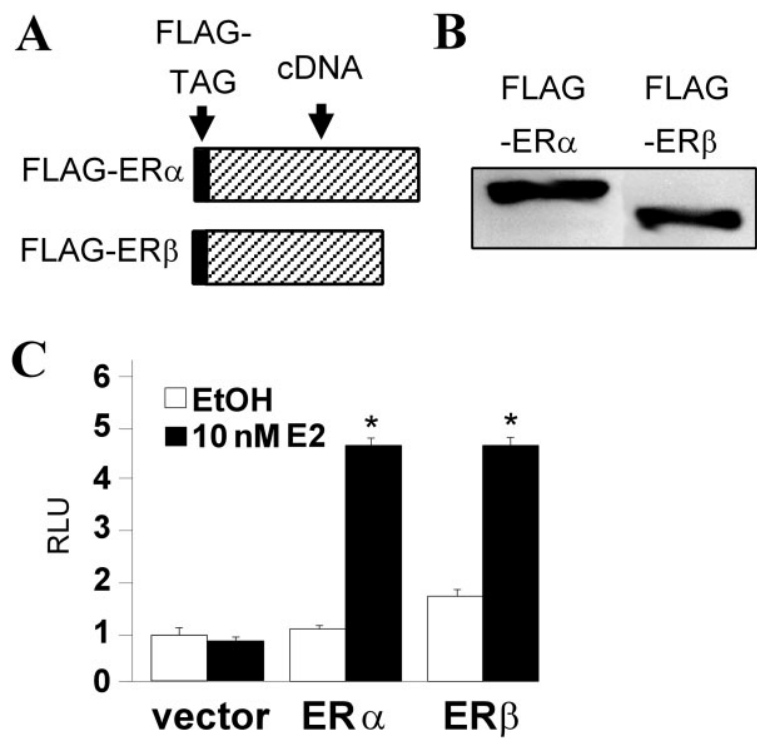

Figure 1 Development of FLAG epitope-tagged (TAG) ER $\alpha$ and ER $\beta$ expression constructs. (A) Expression constructs containing an $\mathrm{N}$-terminal FLAG epitope were constructed using PCR and subcloned into the pcDNA4/TO expression vector. (B) One microgram of each ER-FLAG construct was transfected into hFOB cells. Following $24 \mathrm{~h}$ to allow for expression, the cells were harvested and $75 \mu \mathrm{g}$ total cellular extract was separated by PAGE and transferred to a nitrocellulose membrane. The membrane was probed with an anti-FLAG-M2 antibody and visualized using enhanced chemiluminescence. (C) Ten nanograms of each ER-FLAG construct was cotransfected with $1 \mu \mathrm{g}$ ERE-TK-LUC and $1 \mu \mathrm{g}$ Renilla luciferase construct into hFOB cells. Following a 24-h E2 treatment (10 nM E2), the cells were harvested and assayed for luciferase activity. The bars represent fold induction by E2 \pm S.D. and the asterisks represent significance at the $P<0 \cdot 001$ level (ANOVA) compared with the vehicle (EtOH control).

Total protein extracts were prepared in RIPA buffer $(1 \%$ $(\mathrm{v} / \mathrm{v})$ NP40, $0 \cdot 5 \%(\mathrm{v} / \mathrm{v})$ sodium deoxycholate, $0 \cdot 1 \%$ $(\mathrm{v} / \mathrm{v})$, SDS, and $1 \times$ protease inhibitor cocktail (Roche Diagnostics Corporation, Indianapolis, IN, USA) in $1 \times$ phosphate-buffered saline) and $75 \mu \mathrm{g}$ of the protein extract was subjected to Western blot analysis and detected using an $\alpha$-FLAG-M2 antibody (Sigma) followed by an $\alpha$-mouse IgG secondary antibody (Sigma). The proteins were visualized using an enhanced chemiluminescence kit (Amersham Pharmacia, Piscataway, NJ, USA).

\section{Real-time PCR analysis}

Total cellular RNA from triplicate plates of COS7, MCF7, hFOB, MG63, U2OS, and SaOS2 cells were harvested using Trizol Reagent (Invitrogen). Four micrograms of total RNA were heat denatured at $68^{\circ} \mathrm{C}$ for $15 \mathrm{~min}$ in a reverse transcription reaction buffer $(1 \times 1$ st strand buffer $(50 \mathrm{mM}$ Tris- $\mathrm{HCl}, 75 \mathrm{mM} \mathrm{KCl}, 3 \mathrm{mM}$ $\mathrm{MgCl}_{2}$ ), $50 \mathrm{mM}$ dithiothreitol, $1 \mu \mathrm{M}$ dNTPs, and $500 \mathrm{ng}$ oligo-dT primer). Following heat denaturation, 1 unit
MMLV-RT (Invitrogen) was added and the mixture incubated at $37^{\circ} \mathrm{C}$ for $45 \mathrm{~min}$ followed by a $68^{\circ} \mathrm{C}$ incubation for an additional $15 \mathrm{~min}$. The resultant cDNA products were diluted to $50 \mu \mathrm{l}$ with PCR grade water and $2 \mu \mathrm{l}$ was used in a real-time PCR reaction $(1 \times \mathrm{PCR}$ buffer ( $20 \mathrm{mM}$ Tris- $\mathrm{HCl}, 50 \mathrm{mM} \mathrm{KCl}), 3 \mathrm{mM} \mathrm{MgCl}$, $300 \mathrm{nM}$ of both $5^{\prime}$ and $3^{\prime}$ primer, $1 \times$ Sybr Green (Molecular Probes, Eugene, OR, USA), and 1 unit Taq Polymerase (Promega)). The primer sequences used for real time PCR are as follows: SRC1 $5^{\prime}$ primer $\left(5^{\prime}-\mathrm{TGC}\right.$ CTC CGG GTA TCA GTC ACC AG), SRC1 3' primer (5'-AGG CGT GGG CTG GTT CTG GAC AG), SRC2 5' primer (5'-GTG GTA TGC CAG CAA CTA TGA GC), SRC2 3' primer (5-TGG ATC AGG TTG CTG ACT TAT TCC G), SRC3 5' primer $\left(5^{\prime}\right.$-ACA ACC AGA TCC AGC CTT TGG TC), SRC3 3' primer (5'-TGG ATG CAG CCT GCG GGT GTT GC), $\beta$-actin $5^{\prime}$ primer $\left(5^{\prime}\right.$-TCA CCC ACA CTG TGC CCA TCT ACG A), and $\beta$-actin $3^{\prime}$ primer $\left(5^{\prime}\right.$-CAG CGG AAC CGC TCA TTG CCA ATG G). The reactions were amplified using the I-Cycler (BioRad, Hercules, CA, USA) using the following thermal protocol: 1 cycle at $94{ }^{\circ} \mathrm{C}(1 \mathrm{~min}), 35$ cycles at $94^{\circ} \mathrm{C}(30 \mathrm{~s}), 65^{\circ} \mathrm{C}(30 \mathrm{~s})$, and $72{ }^{\circ} \mathrm{C}(30 \mathrm{~s})$. The $\mathrm{C}_{\mathrm{T}}$ measurement is defined at the fractional cycle number at which the amount of amplified target reaches a fixed threshold above background Sybr Green fluorescence. The amount of target in the cDNA sample relative to $\beta$-actin was calculated by the formula: $2^{-\Delta \Delta \mathrm{C}_{\mathrm{T}}}$, where $\Delta \Delta \mathrm{C}_{\mathrm{T}}$ is the difference between the average $\mathrm{C}_{\mathrm{T}}$ value for the target (SRC1, SRC2, or SRC3) and $\beta$-actin.

\section{Results}

Development of FLAG-tagged ER expression constructs and determination of transfection conditions

For this study, N-terminal FLAG epitope-tagged ER $\alpha$ and ER $\beta$ expression constructs were developed (see Materials and Methods and Fig. 1A). Figure 1B demonstrates that transfection of equimolar amounts of $\operatorname{ER} \alpha$ and $\operatorname{ER} \beta$ expression construct in hFOB cells produces proteins of $66 \mathrm{kDa}$ and $54 \mathrm{kDa}$ respectively, which are expressed at approximately equal levels. To demonstrate that these receptors are functional, either the ER $\alpha-$ FLAG or ER $\beta$ FLAG construct was transiently co-transfected with an ERE-reporter construct into hFOB. Figure 1C demonstrates that these receptors are functional, i.e. displays E2-inducible transcription of an ERE-dependent reporter gene when the cells were treated with E2. Under these conditions, each isoform exhibits a comparable activity. In order to determine the optimal amount of expression construct to achieve the maximal transcriptional response, a titration of ER $\alpha-$ FLAG and ER $\beta-$ FLAG expression constructs was performed in hFOB cells. Interestingly, Fig. 2 demonstrates that cells containing the lowest 


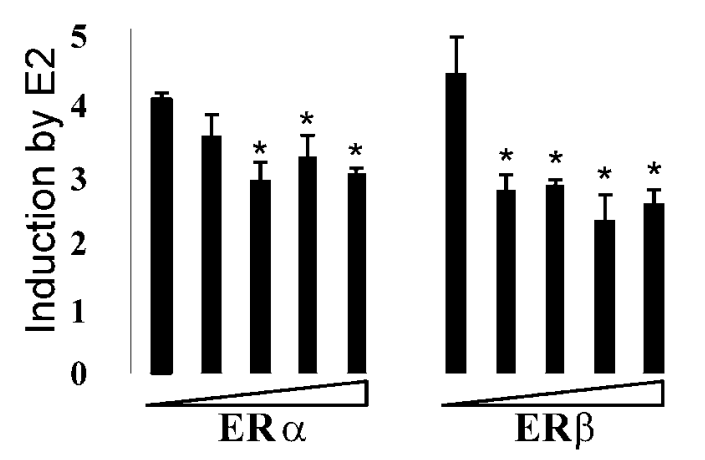

Figure 2 The effect of cotransfecting different ER amounts into hFOB cells on the ERE reporter gene activity under E2 stimulation. Increasing amounts of ER $\alpha$ or ER $\beta$ expression construct (10, 20, 40, 60, $80 \mathrm{ng}$ ) were cotransfected with $1 \mu \mathrm{g}$ ERE-TK-LUC and $1 \mu \mathrm{g}$ Renilla luciferase into hFOB cells. Following a 24-h E2 treatment $(10 \mathrm{nM})$, the cells were harvested and assayed for luciferase activity. The bars represent fold induction by E2 \pm S.D. and the asterisks represent significance at the $P<0 \cdot 01$ level (ANOVA) compared with the $10 \mathrm{ng}$ data point for each ER $\alpha$ and ER $\beta$ titration.

amounts of the transfected ER constructs (10 ng) display the greatest fold of E2-inducible transcription (approximately fourfold) for both ER isoforms. Other experiments, using $5 \mathrm{ng}$ ER, demonstrated similar levels of induction as the $10 \mathrm{ng}$ dose (data not shown). Therefore, $10 \mathrm{ng}$ total ER expression construct(s) was used throughout this study.

\section{$E R \alpha$ and $E R \beta$ coexpression exhibits lowered transactivation capacity in $O B s$ but not in non-OBs}

Gene deletion experiments in mice suggest that ER $\alpha$ and ER $\beta$ have opposing actions on bone growth (Korach et al. 1996, Windahl et al. 1999). Therefore, since ER $\alpha$ and ER $\beta$ are coexpressed in OBs (Arts et al. 1997, Rickard et al. 2000), we tested the hypothesis that coexpression of $E R \alpha$ and ER $\beta$ has an antagonistic effect on EREdependent (E2-inducible) reporter activity. Figure 3A demonstrates that expression of ER $\alpha$ or ER $\beta$ alone (10 ng each) results in equivalent E2 induction of EREdependent transcription in hFOB cells. Interestingly, coexpression of equimolar amounts of ER $\alpha$ and ER $\beta$ (10 ng total ER) results in a statistically significant 31\% decrease in E2-inducible transcription in hFOB cells (Fig. 3A). Similar results are shown in MG63 osteosarcomas, which also lack detectable endogenous ER expression (Lambertini et al. 2002), where a statistically significant $47 \%$ decrease in E2-inducible transcription was observed (Fig. 3B). This demonstrates that various $\mathrm{OB}$ cell lines, coexpressing both ER $\alpha$ and $\operatorname{ER} \beta$ in equimolar ratios, exhibit diminished E2-inducible responses. Since it is well established in the literature that coexpression of equimolar amounts of ER $\alpha$ and ER $\beta$ expression construct results in primarily heterodimer formation (Cowley et al. 1997, Tremblay et al. 1999), these studies reflect the transcrip-
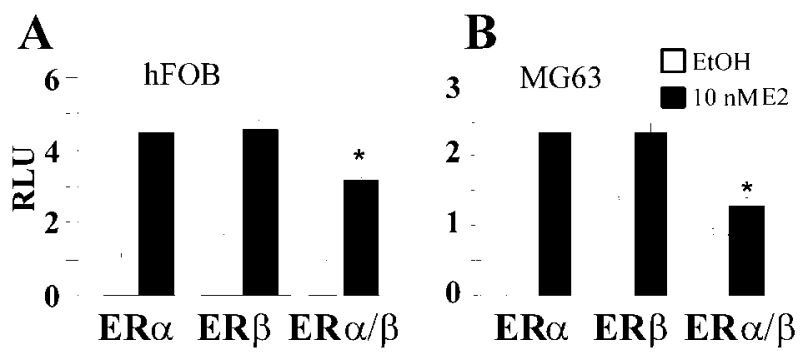

Figure $3 \mathrm{ER} \alpha$ and $E R \beta$ coexpression results in transcriptional antagonism on ERE-reporter activity in hFOB cells and MG63 osteosarcomas. (A) ER $\alpha(10 \mathrm{ng}), \mathrm{ER} \beta(10 \mathrm{ng})$, or $\mathrm{ER} \alpha(5 \mathrm{ng})$ and $\operatorname{ER} \beta(5 \mathrm{ng})$ together $(\mathrm{ER} \alpha / \beta)$ were cotransfected with $1 \mu \mathrm{g}$ ERE-TK-LUC and $1 \mu \mathrm{g}$ Renilla luciferase into hFOB cells. Following a 24-h E2 treatment (10 nM E2), the cells were harvested and assayed for luciferase activity. (B) This panel represents the identical experimental procedure as in $(A)$ except that the transfected cells were MG63 osteosarcoma cells. Each experimental condition was performed in triplicate and a representative experiment is shown. Luciferase values represent the means \pm S.D. and the asterisks represent significance at the $P<0.001$ level (ANOVA).
A

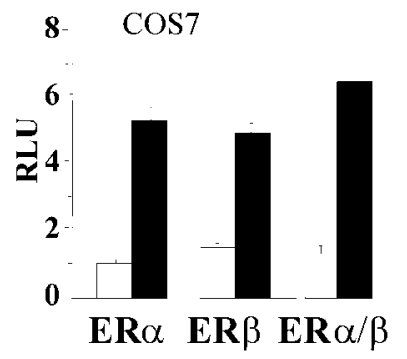

B

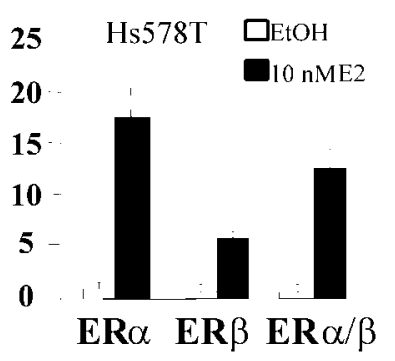

Figure $4 \mathrm{ER} \alpha$ and $E R \beta$ coexpression does not result in transcriptional antagonism on ERE-reporter activity in COS7 and $\mathrm{Hs} 578 \mathrm{~T}$ cells. (A) A total of $10 \mathrm{ng} E R \alpha, E R \beta$, or ER $\alpha$ and $E R \beta$ together $(\mathrm{ER} \alpha / \beta)$ were cotransfected with $1 \mu \mathrm{g}$ ERE-TK-LUC and $1 \mu \mathrm{g}$ Renilla luciferase into COS7 cells. Following a 24-h E2 treatment (10 $\mathrm{nM} \mathrm{E2),} \mathrm{the} \mathrm{cells} \mathrm{were} \mathrm{harvested} \mathrm{and} \mathrm{assayed} \mathrm{for}$ luciferase activity. Luciferase values represent the means \pm S.D. (B) This panel represents the identical experimental procedure as in (A) except that the transfected cells were Hs578T breast carcinoma cells. Each experimental condition was performed in triplicate and a representative experiment is shown.

tional effects of the ER $\alpha / \beta$ heterodimer and $E R \alpha$ and ER $\beta$ homodimers on ERE-dependent promoter activity. Furthermore, these data suggest that the ER heterodimer has a unique transcriptional function since its E2-inducible activity is significantly lower than either ER isoform alone.

To examine the cell type specificity of this ER isoform antagonism, similar experiments were conducted in the monkey kidney cell line, COS7, and the human breast carcinoma, Hs578T, both of which lack detectable endogenous ER expression (Gopalakrishna et al. 1999, Kahlert et al. 2000). Figure $4 \mathrm{~A}$ demonstrates that the coexpression of ER $\alpha$ and ER $\beta$ in COS7 cells results in no difference in E2-inducible transcription compared with 
either isoform alone. In contrast, in Hs578T cells, ER $\beta$ had weaker transcriptional activation capability compared with ER $\alpha$ and coexpression of ER $\alpha$ and ER $\beta$ resulted in an activity intermediate to either ER isoform alone (Fig. 4B). Importantly, coexpression of $\mathrm{ER} \alpha$ and $\mathrm{ER} \beta$ in

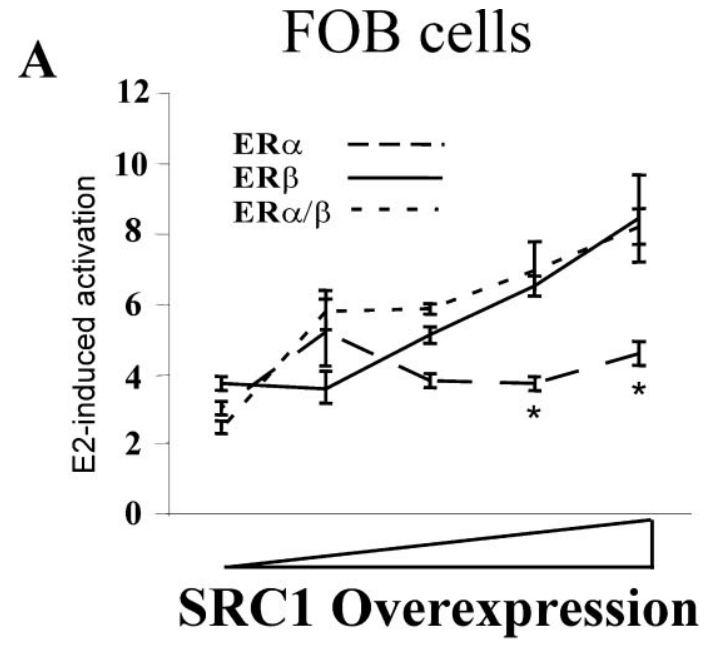

B
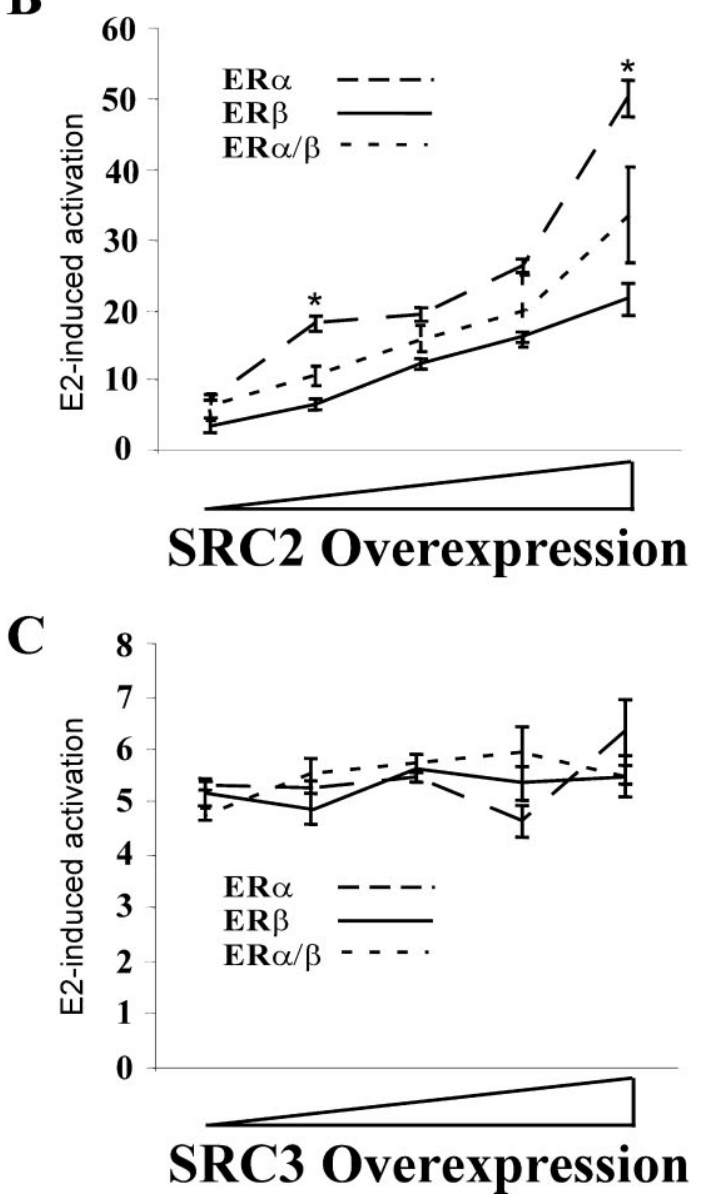

Hs578T cells does not exhibit a similar type of transcriptional antagonism as seen in OBs, where coexpressed ER $\alpha$ and $E R \beta$ resulted in lowered E2-inducible activity than either ER isoform alone (Fig. 3). Notably, the observation that $\mathrm{ER} \beta$ is a weaker activator than ER $\alpha$ in Hs578T cells has been described in other non-OB cell types (i.e. Hep2 G cells) (Hall \& McDonnell 1999), demonstrating fundamental differences between the ER $\beta$ and ER $\alpha$ homodimer activities when expressed in breast carcinoma and $\mathrm{OB}$ cells.

Enhancement of ER signaling by SRCs is both SRC and cell type dependent

Transcriptional responses elicited by the ER are mediated by a group of nuclear transcription factors termed 'steroid receptor coactivators' or SRCs (McKenna et al. 1999). The specific modulation of SRC expression levels or their coactivation properties with ER may explain the transcriptional differences of ER function in different cell types (Figs 3 and 4). Although SRC-dependent coactivation of both ER isoforms has been demonstrated in some cell types, the effects of SRC coexpression on ER function in OBs have not been explored. Therefore, in order to understand the contribution of SRC1, SRC2, and SRC3 to E2 responses in hFOBs, titration of these SRC molecules with either ER isoform alone, or coexpressed ER $\alpha$ and ER $\beta$, was performed. Titration of the SRC1 expression construct ranging from 0 to $80 \mathrm{ng}$ resulted in only a slight enhancement of ER $\alpha$-dependent transcription on the ERE-luciferase construct (Fig. 5A). However, overexpression of SRC1 resulted in a dose-dependent enhancement of ER $\beta$-dependent transcription (Fig. 5A). The results support a preferential enhancement of $E R \beta$ function. The transcriptional enhancement of coexpressed $\mathrm{ER} \alpha$ and $\mathrm{ER} \beta$, reported in the literature to create primarily heterodimers (Cowley et al. 1997, Tremblay et al. 1999), appeared similar to that of ER $\beta$ at higher SRC1 concentrations. Titration of SRC2 resulted in a dosedependent enhancement in cells containing ER $\alpha, \operatorname{ER} \beta$, or

Figure 5 Overexpression of SRC1, SRC2, or SRC3 results in an SRC-specific and ER isoform-specific enhancement of E2-dependent transcription in hFOB cells. Ten nanograms of ER $\alpha$, $E R \beta$, or $E R \alpha$ and $E R \beta(E R \alpha / \beta)$ was cotransfected with $1 \mu \mathrm{g}$ ERE-TK-LUC, $1 \mu \mathrm{g}$ Renilla luciferase, and increasing concentrations $(0,20,40,60,80 \mathrm{ng})$ of (A) SRC1, (B), SRC2, or (C) SRC3 expression constructs into hFOB cells. Following a 24-h E2 treatment $(10 \mathrm{nM})$, the cells were harvested and assayed for luciferase activity. Luciferase values represent the means \pm S.D. The asterisks in (A) denote statistical significance between ER $\alpha$ and $E R \beta$ or $E R \alpha / \beta$ at the $P<0.001$ level (ANOVA). The asterisks in (B) denote statistical significance among all ER combinations at the $P<0 \cdot 01$ level (ANOVA). Since estrogen-independent effects of SRC overexpression were not observed, only the data points representing estrogen treatment are shown. Each experimental condition was performed in triplicate and a representative experiment is shown. 
coexpressed ER $\alpha$ and ER $\beta$; however, SRC2 consistently enhanced $E R \alpha$-dependent transcription to a greater extent than ER $\beta$ (Fig. 5B). The coexpression of ER $\alpha$ and $\operatorname{ER} \beta$ results in an intermediate transcriptional activity of either ER isoform alone. Surprisingly, overexpression of

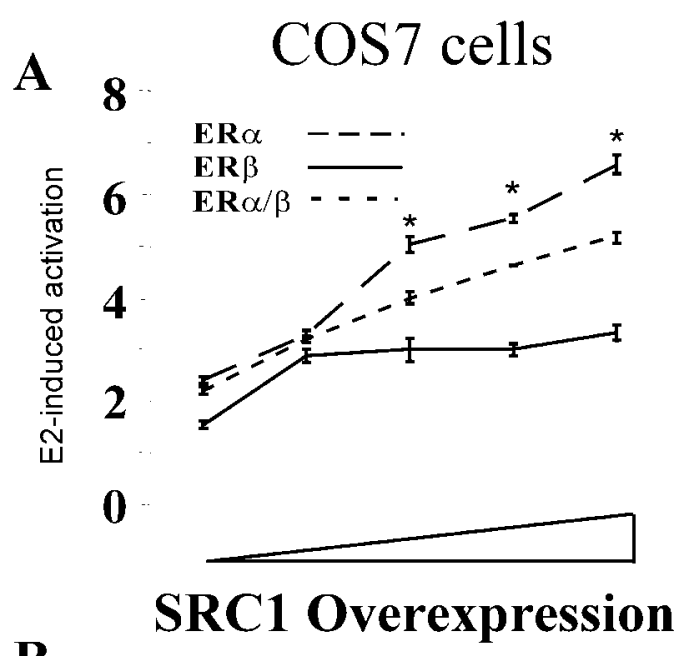

B

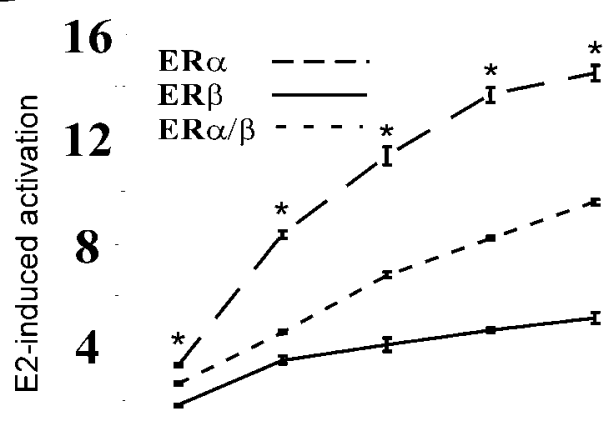

0

SRC2 Overexpression

C

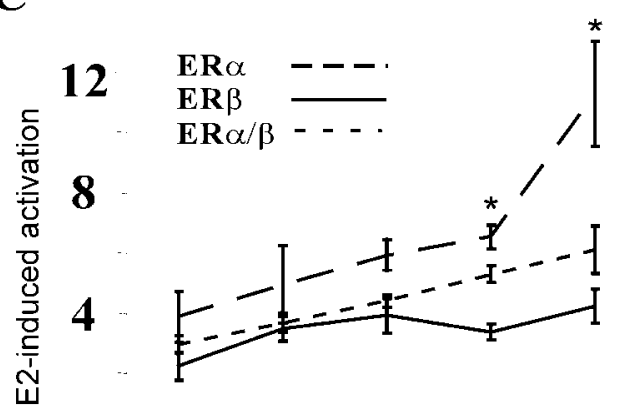

0

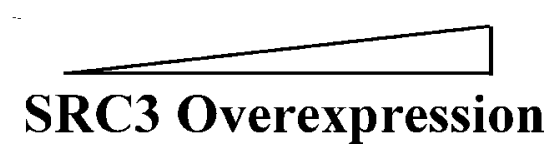

SRC3 had no statistically significant effect on transcriptional enhancement with any ER isoform combination tested (Fig. 5C).

To examine the cell type specificity of these SRCdependent responses, similar studies were conducted in COS7 cells. Figure 6A-C demonstrates that ER $\alpha$ function is enhanced to a greater extent than that of $\operatorname{ER} \beta$ by all the SRCs tested, and that the transcriptional enhancement of coexpressed ER $\alpha$ and $\operatorname{ER} \beta$ appears intermediate to either ER isoform alone in the presence of all the SRCs. Thus, the preferential enhancement of SRC-dependent coactivation, as observed in Fig. 5 with hFOB cells, was not observed in COS7 cells. This demonstrates an apparent cell type preference of SRC function with the various ER dimers.

SRC3 $m R N A$ is reduced in osteoblastic cell lines when compared with non-osteoblastic cell lines

A plausible explanation for the lack of transcriptional enhancement of SRC3 with any ER combination in the $\mathrm{hFOB}$ cells is that sufficient SRC3 is already present in these cells and that additional (e.g. transfected) SRC3 will not increase the ER-mediated transcriptional response.

Therefore, we examined the relative levels of endogenous SRC1, SRC2, and SRC3 mRNAs in hFOB and COS7 cells using real-time PCR. Figure 7 demonstrates that no statistically significant difference was observed in SRC1 and SRC2 mRNA levels between the hFOB and COS7 cells. However, a 20-fold decrease in SRC3 mRNA was observed in hFOB cells when compared with COS7 cells, strengthening the notion that sufficient SRC3 is not present in hFOB cells to increase ER transactivation. To further explore this phenomenon, SRC3 mRNA levels were examined in another non-OB cell line, MCF7, and three additional human osteoblastic cell lines (MG63, $\mathrm{U} 2 \mathrm{OS}$, and $\mathrm{SaOS} 2$ ). Figure 8 demonstrates that all the osteoblastic cell lines tested have significantly reduced SRC3 mRNA levels when compared with either COS7 or MCF7 cells.

Figure 6 Overexpression of SRC1, SRC2, or SRC3 results in preferential enhancement of E2-dependent transcription by ER $\alpha$ in COS7 cells. Ten nanograms of ER $\alpha, E R \beta$, or $E R \alpha$ and $E R \beta(E R \alpha / \beta)$ were cotransfected with $1 \mu \mathrm{g}$ ERE-TK-LUC, $1 \mu \mathrm{g}$ Renilla luciferase, and increasing concentrations $(0,20,40,60,80 \mathrm{ng})$ of (A) SRC1, (B), SRC2, or (C) SRC3 expression constructs into COS7 cells. Following a 24-h E2 treatment $(10 \mathrm{nM})$, the cells were harvested and assayed for luciferase activity. Luciferase values represent the means \pm S.D. All asterisks denote statistical significance among all ER combinations at the $P<0.001$ level (ANOVA). Since estrogen-independent effects of SRC overexpression were not observed, only the data points representing estrogen treatment are shown. Each experimental condition was performed in triplicate and a representative experiment is shown. 


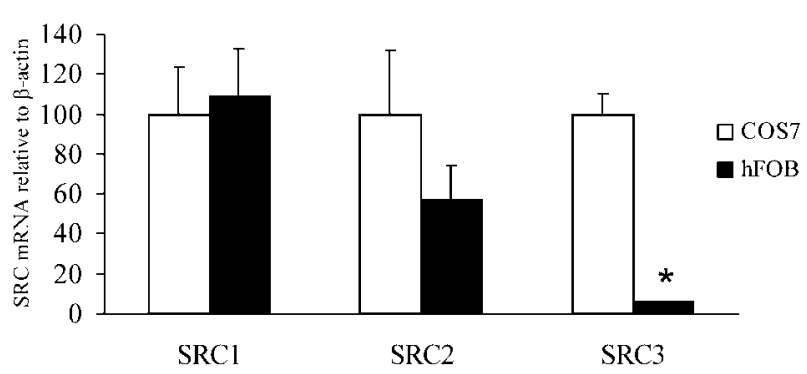

Figure 7 Comparison of SRC1, SRC2, and SRC3 mRNA levels demonstrates reduced SRC3 mRNA in hFOB cells. mRNA from COS7 and hFOB cells were subjected to RT-PCR using real-time PCR technology as described in the Materials and Methods section. The data are plotted relative to $\beta$-actin and normalized to the COS7 data (arbitrarily set at 100). Values represent the means \pm S.D. $(n=3)$ and the asterisk denotes statistical significance at the $P<0 \cdot 001$ level (ANOVA).

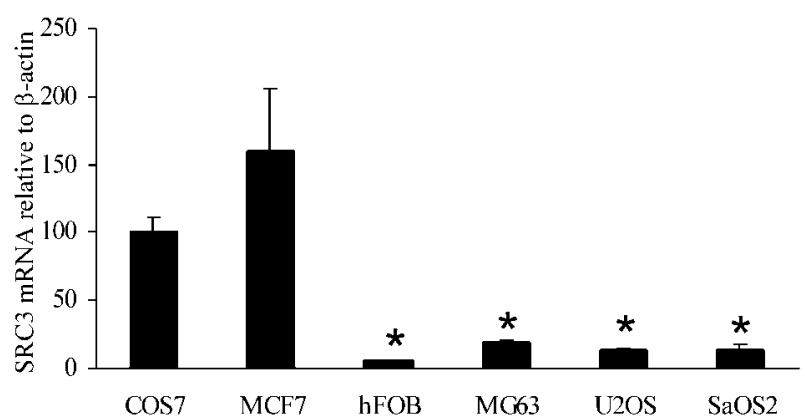

Figure 8 SRC3 mRNA levels are reduced in various osteoblastic cells compared with non-osteoblastic cells. mRNA from COS7, MCF7, hFOB, MG63, U2OS, and SaOS2 cells were subjected to RT-PCR using real-time PCR technology as described in the Materials and Methods section. The data are plotted relative to $\beta$-actin and normalized to the COS7 data (arbitrarily set at 100). Values represent the means \pm S.D. $(n=3)$ and the asterisks denote statistical significance at the $P<0 \cdot 001$ level (ANOVA).

\section{Discussion}

This report addresses two important and largely unexplored aspects of ER function in OBs; the function of $\operatorname{ER} \alpha$ and ER $\beta$ coexpression and the effects of SRC overexpression on E2-dependent transcription. We have demonstrated that dual expression of ER $\alpha$ and ER $\beta$ in either hFOB or MG63 osteosarcoma results in an estrogen-dependent transcriptional response that is $31 \%$ and $47 \%$ lower respectively than either ER isoform acting alone. Similar experiments in two non-OB cell lines, COS7 and Hs578T, failed to exhibit the same transcriptional antagonism when ER $\alpha$ and ER $\beta$ were coexpressed, suggesting that transcriptional antagonism elicited by ER $\alpha$ and $\operatorname{ER} \beta$ coexpression is a cell type-specific phenomenon.

Earlier studies demonstrated that the ratio of $\operatorname{ER} \alpha: \operatorname{ER} \beta$ changes significantly throughout OB differentiation (Arts et al. 1997). Our data demonstrating lowered activation potential when ER $\alpha$ and ER $\beta$ are coexpressed suggest that altering $E R \alpha$ and $E R \beta$ ratios (which presumably shifts the balance of ER homo- and heterodimers) during OB differentiation may potentially have important implications in the overall magnitude of estrogen responses. These data suggest that factors other than ER $\alpha / \beta$ heterodimerization itself, presumably cell type-specific factors, are responsible for determining the degree of E2-dependent transcription at a classical ERE in various cell types. We are currently investigating how dual expression of both ER isoforms would affect different classes of E2-responsive elements (i.e. $\frac{1}{2} \mathrm{ERE} / \mathrm{SP} 1$ and AP1 elements) in this human $\mathrm{OB}$ system.

A potential mechanism explaining the differences in ER activity in divergent cell types (OB versus non-OB) may involve the differential expression or recruitment of transcriptional accessory factors, such as the SRCs. Therefore, we overexpressed SRC1, SRC2, and SRC3 with various ER isoform combinations to test this hypothesis. We have demonstrated that in hFOB cells, the overexpression of SRC1 preferentially enhances ER $\beta$-induced transcription whereas SRC2 enhances ER $\alpha$-induced transcription to a greater extent than either $\operatorname{ER} \beta$ or coexpressed $\operatorname{ER} \alpha$ and ER $\beta$. This finding may have fundamentally important implications on the activation of estrogen-responsive genes that are dependent on a classical ERE for activation. The activation of certain genes would be theoretically dependent on the particular ER dimer bound at the promoter, the concentration of each coactivator in the $\mathrm{OB}$ nucleus, and possibly the promoter element involved. Our hypothesis is that the modulation of ER dimers (e.g. homo- or heterodimers), as occurs in in vivo osteoblastic differentiation (Arts et al. 1997), acts to 'select' a particular set of accessory factors (e.g. SRCs) for transcriptional activation. Interestingly, recent biochemical purification of SRC1 and SRC3 from HeLa nuclear extracts revealed that these coactivators reside in unique complexes containing unique enzymatic activities (Wu et al. 2002). Therefore, specific ER dimers may determine the affinity for a particular coactivator complex and elicit specific coactivation functions based on which coactivator complex is recruited. Further delineation of the specific SRC complexes involved in the regulation of estrogen-responsive genes and of how the ER dimers differentially interact with these coactivator complexes would significantly aid in testing this hypothesis.

Our data also suggest that the patterns of SRCdependent coactivation of transcription with a particular ER dimer is a tissue-specific phenomenon, as SRC1, SRC2, or SRC3 overexpression enhanced ER $\alpha$-induced transcription to higher levels than either ER $\beta$ or coexpressed ER $\alpha$ and ER $\beta$ in COS7 cells. This agrees with a previous observation of SRC1 enhancement of ER $\alpha-$ induced transcription in COS1 cells (Sheppard et al. 2001). More specifically, our data extend this observation to demonstrate that SRC2 and SRC3 overexpression also preferentially enhances ER $\alpha$-induced transcription over that of either ER $\beta$ or coexpressed ER $\alpha$ and ER $\beta$. Taken 
together with the observation of SRC overexpression in hFOBs, these data suggest that fundamental differences exist in the ability of SRCs to enhance ER isoform function that is critically dependent on the cell type. This also demonstrates that the lack of ER-induced transcriptional enhancement in hFOB cells with SRC3 is a biologically relevant phenomenon, and not due to technical issues with the SRC3 construct, since SRC3 enhanced ER $\alpha$-dependent transcription in the COS7 cell line.

A plausible mechanism to explain the differences in the responses of various ER dimers to a particular SRC within a specific cell type may lie in the physical interaction interface between the ER and SRC molecules. Previous studies demonstrated the stoichiometry for ER-SRC interactions are one SRC molecule per ER dimer (Kalkhoven et al. 1998, Tremblay et al. 1999). Therefore, the SRC interaction interface is unique depending on whether ER $\alpha$ homodimers, ER $\beta$ homodimers, or ER $\alpha / \beta$ heterodimers are present at the ERE. Our data suggest that these unique interaction surfaces may be critically important in determining the strength of coactivation depending on which SRC molecule is present. Recent reports have demonstrated that variations in ERE sequences influence the magnitude of SRC coactivation of ER function (Hall et al. 2002) which, in turn, is also affected by various estrogenic compounds (Bramlett et al. 2001, Hall et al. 2002). However, the novelty of our data lies in the demonstration that SRCs can affect estrogen signaling at the same ERE with the same ligand (e.g. E2) in different ways dependent on the ER dimer and cell type.

An extreme example of this cell-specific coactivation is illustrated with the overexpression of SRC3 having no effect on ER-induced transcription in OBs compared with the statistically significant effects of SRC3 overexpression in COS7 cells. Thus, it appears that osteoblastic cells are somehow impaired in their capability to utilize SRC3 in estrogenic responses, possibly due to factors specific to cell types other than OBs. Our data also indicate that comparatively low levels of endogenous SRC3 exist in multiple osteoblastic cell lines. Collectively, these observations suggest that SRC3 has little function in mediating estrogenic responses in osteoblastic cells and that these responses are most likely dependent on SRC1 and/or SRC2 coactivation of the ER.

In summary, the present study serves to address two fundamental aspects of ER signaling that occurs in OBs. First, the notion that ER $\alpha$ and $E R \beta$ coexpression results in transcriptional antagonism in $\mathrm{OBs}$, as suggested by the bone phenotypes of the ERKO (Couse \& Korach 1999) and BERKO (Windahl et al. 1999) gene disruption mouse models (ER $\alpha$ and ER $\beta$ respectively). Secondly, to characterize the transcriptional responses of the ER isoforms (homo- and heterodimers) to the nuclear receptor coactivators, SRC1, SRC2, and SRC3. The responses of ER homo- and heterodimers to SRC overexpression illuminate an alternative form of transcriptional regulation that is dependent on the ER dimerization status, the specific SRC present at the promoter, and the cell type.

\section{Acknowledgements}

We thank Dr Bert O'Malley for providing the SRC1 expression construct (Onate et al. 1995), Dr Pierre Chambon for the TIF2 (SRC2) expression construct (Voegel et al. 1996), and Dr Paul Meltzer for the AIB-1 (SRC3) expression construct (Anzick et al. 1997). This work was supported by an NIH grant (PO1-AG04875), NIH training grant CA09441, and the Mayo Foundation.

\section{References}

Anzick SL, Kononen J, Walker RL, Azorsa DO, Tanner MM, Guan XY, Sauter G, Kallioniemi OP, Trent JM \& Meltzer PS 1997 AIB1, a steroid receptor coactivator amplified in breast and ovarian cancer. Science 277 965-968.

Arts J, Kuiper GGJM, Janssen JMMF, Gustafsson J-A, Lowik CWGM, Pols HAP \& Van Leeuwen PTM 1997 Differential expression of estrogen receptors $\alpha$ and $\beta$ mRNA during differentiation of human osteoblasts SV-HFO cells. Endocrinology 138 5067-5070.

Bramlett KS, Wu Y \& Burris TP 2001 Ligands specific coactivator nuclear receptor (NR) box affinity for estrogen receptor subtypes. Molecular Endocrinology 15 909-922.

Couse JF \& Korach KS 1999 Estrogen receptor null mice: what have we learned and where will they lead us? Endocrine Reviews $\mathbf{2 0}$ 358-417.

Cowley SM, Hoare S, Mosselman S \& Parker MG 1997 Estrogen receptors alpha and beta form heterodimers on DNA. Journal of Biological Chemistry 272 19858-19862.

Gopalakrishna R, Gundimeda U, Fontana JA \& Clarke R 1999 Differential distribution of protein phosphatase $2 \mathrm{~A}$ in human breast carcinoma cell lines and its relation to estrogen receptor status. Cancer Letters 136 143-151.

Hall JM \& McDonnell DP 1999 The estrogen receptor $\beta$ isoform $(\mathrm{ER} \beta)$ of the human estrogen receptor modulates $\operatorname{ER} \alpha$ transcriptional activity and is a key regulator of cellular response to estrogens and antiestrogens. Endocrinology 140 5566-5578.

Hall JM, McDonnell DP \& Korach KS 2002 Allosteric regulation of estrogen receptor structure, function, and coactivator recruitment by different estrogen response elements. Molecular Endocrinology 16 469-486.

Harris SA, Enger RJ, Riggs BL \& Spelsberg TC 1995 Development and characterization of a conditionally immortalized human fetal osteoblastic cell line. Journal of Bone and Mineral Research $\mathbf{1 0}$ 178-186.

Kahlert S, Nuedling S, van Eickels M, Vetter H, Meyer R \& Grohe C 2000 Estrogen receptor alpha rapidly activates the IGF-1 receptor pathway. Journal of Biological Chemistry 275 18447-18453.

Kalkhoven E, Valentine JE, Heery DM \& Parker MG 1998 Isoforms of steroid receptor co-activator 1 differ in their ability to potentiate transcription by the oestrogen receptor. EMBO Journal 17 232-243.

Korach KS, Couse JF, Curtis SW, Washburn TF, Lindzey J, Kimbro KS, Eddy EM, Migliaccio S, Snedeker SM, Lubahn DB, Schomberg DW \& Smith EP 1996 Estrogen receptor gene disruption: molecular characterization and experimental and clinical phenotypes. Recent Progress in Hormone Research 51 159-186.

Kuiper GGJM, Enmark E, Pelto-Huikko M, Nilsson S \& Gustafsson J-Å 1996 Cloning of a novel estrogen receptor expressed in rat prostate and ovary. PNAS 93 5925-5930. 
Lambertini E, Penolazzi L, Aguiari G, del Senno L, Pezzetti F, Sollazzo V \& Piva R 2002 Osteoblastic differentiation induced by transcription factor decoy against estrogen receptor alpha gene. Biochemical and Biophysical Research Communications 292 761-770.

Li H, Gomes PJ \& Chen JD 1997 RAC3, a steroid/nuclear receptor-associated coactivator that is related to SRC-1 and TIF2. PNAS 94 8479-8484.

Lindberg MK, Moverare S, Skrtic S, Alatalo S, Halleen J, Mohan S, Gustafsson J-Å \& Ohlsson C 2002 Two different pathways for the maintenance of trabecular bone in adult male mice. Journal of Bone and Mineral Research 17 555-562.

Mangelsdorf DJ, Thummel C, Beato M, Herrlich P, Schutz G, Umesono K, Blumberg B, Kaster P, Mark M, Chambon P \& Evans RM 1995 The nuclear receptor superfamily: the second decade. Cell 83 835-839.

McKenna NJ, Lanz RB \& O'Malley BW 1999 Nuclear receptor coregulators: cellular and molecular biology. Endocrine Reviews 20 321-344.

Mosselman S, Polman J \& Dijkema R 1996 ER $\beta$ : identification and characterization of a novel human estrogen receptor. FEBS Letters 392 49-53.

Onate SA, Tsai SY, Tsai MJ \& O’Malley BW 1995 Sequence and characterization of a coactivator for the steroid hormone receptor superfamily. Science 270 1354-1357.

Paech K, Webb P, Kuiper GGJM, Nilsson S, Gustafsson J-Å, Kushner PJ \& Scanlan TS 1997 Differential ligand activation of estrogen receptors ER $\alpha$ and ER $\beta$ at AP1 sites. Science 277 1508-1510.

Pettersson K, Delaunay F \& Gustafsson J-Å 2000 Estrogen receptor $\beta$ acts as a dominant regulator of estrogen signaling. Oncogene $\mathbf{1 9}$ 4970-4978.

Rickard D, Harris SA, Turner R, Khosla S \& Spelsberg TC 2000 Estrogen and progestins. In Principles of Bone Biology, edn 2, pp 655-676. Eds P Bilezikian, LG Raisz \& GA Rodan. San Diego: Academic Press.

Sheppard HM, Harries JC, Hussain S, Bevan C \& Heery DM 2001 Analysis of the steroid receptor coactivator 1 (SRC1)-CREB binding protein interaction interface and its importance for the function of SRC1. Molecular and Cellular Biology 21 39-50.

Sims NA, Dupont S, Krust A, Clement-Lacroix P, Minet D, Resche-Rigon M, Gaillard-Kelly M \& Baron R 2002 Deletion of estrogen receptors reveals a regulatory role for estrogen receptor-b in bone remodeling in females but not in males. Bone 30 18-25.

Smith EP, Boyd J, Frank GR, Takahashi H, Cohen RM, Specker B, Williams TC, Lubahn DB \& Korach KS 1994 Estrogen resistance caused by a mutation in the estrogen receptor gene in a man. New England Journal of Medicine 331 1056-1061.

Tremblay GB, Tremblay A, Copeland NG, Gilbert DJ, Jenkins NA, Labrie F \& Giguere V 1997 Cloning, chromosomal location and functional analysis of the murine estrogen receptor $\beta$. Molecular Endocrinology 11 353-365.

Tremblay GB, Tremblay A, Labrie F \& Giguere V 1999 Dominant activity of activation function 1 (AF1) and differential stoichiometric requirements for AF- 1 and -2 in the estrogen receptor $\alpha-\beta$ heterodimeric complex. Molecular and Cellular Biology 19 1919-1927.

Voegel JJ, Heine MJ, Zechel C, Chambon P \& Gronemeyer H 1996 TIF2, a $160 \mathrm{kDa}$ transcriptional mediator for the ligand-dependent activation function AF-2 of nuclear receptors. EMBO Journal 15 3667-3675.

Weiss RE, Xu J, Ning G, Pohlenz J, O'Malley BW \& Refetoff S 1999 Mice deficient in the steroid receptor co-activator 1 (SRC1) are resistant to thyroid hormone. EMBO Journal 18 1900-1904.

Windahl S, Vidal O, Andersson G, Gustafsson J-Å \& Ohlsson C 1999 Increased cortical bone mineral content but unchanged trabecular bone mineral density in adult female estrogen receptor $\beta-/-$ mice. Journal of Clinical Investigation 104 895-901.

Wu R-C, Qin J, Hashimoto Y, Wong J, Xu J, Tsai SY, Tsai MJ \& O'Malley BW 2002 Regulation of SRC-3 (pCIP/ACTR/AIB-1/ RAC-3/TRAM-1) coactivator activity by IKB kinase. Molecular and Cellular Biology 22 3549-3561.

Xu J, Qiu Y, DeMayo FJ, Tsai SY, Tsai MJ \& O’Malley BW 1998 Partial hormone resistance in mice with disruption of the steroid receptor coactivator-1 (SRC-1) gene. Science 279 1922-1925.

Xu J, Liao L, Ning G, Yoshida-Komiya H, Deng C \& O'Malley BW 2000 The steroid receptor coactivator SRC3 (pCIP/RAC3/AIB1/ ACTR/TRAM-1) is required for normal growth. PNAS $\mathbf{9 7}$ 6379-6384.

Yi P, Driscoll MD, Huang J, Bhagat S, Hilf R, Bambara RA \& Muyan M 2002 The effects of estrogen-responsive element- and ligand-induced structural changes on the recruitment of cofactors and transcriptional responses by $\operatorname{ER} \alpha$ and $\operatorname{ER} \beta$. Molecular Endocrinology 16 674-693.

Received in final form 5 November 2002 Accepted 7 November 2002 